\title{
The Institutional and Legal Framework Of Emerging Capital Markets: The Experience Of Cis Countries
}

\author{
${ }^{1}$ Said Gulyamov, ${ }^{2}$ Otabek Narziev \\ ${ }^{1}$ Doctor of Law, Professor, Department of International private law, Tashkent state university of Law, Tashkent, \\ Uzbekistan. \\ ${ }^{2} \mathrm{PhD}$ in Law, Department of International private law, Tashkent state university of Law, Tashkent, Uzbekistan. \\ E-mail address: s.gulyamov@tsul.uz
}

Article History:Received:11 January 2021; Accepted: 27 February 2021; Published online: 5 April 2021

\begin{abstract}
The present study focuses on the development of one of the key institutions of the market economy - namely, the securities market in terms of its role in promoting competitive conditions in the financial services sector. Due to a variety of objective and subjective factors, banks have become the most dominant institutions in all CIS countries in terms of, both, accumulating and redistributing financial resources. Particularly, the research outlines the background to capital market formation and development in CIS countries through a brief history of the CIS; considers the necessity of capital market and its regulation in CIS countries; reviews the institutional and legal framework of capital market regulation, and analyzes certain problems of capital market development.
\end{abstract}

KEYWORDS: Capital market development, market regulation, CIS countries, legal framework, Russian capital market, Uzbekistan capital market, Kazakhstan capital market.

\section{INTRODUCTION}

The capital market is an indispensable tool of economic development and plays a key role in today's global financial economy, where transactions are carried out electronically and across international borders. It is especially crucial for CIS countries the significant parts of which comprise landlocked countries (Azerbaijan, Armenia, Belarus, Kazakhstan, Kyrgyzstan, Tajikistan, and Uzbekistan). Capital market supplies the economy with the mechanism that helps issuers to accumulate financial resources of investors; and investors to multiply their savings by investing funds in securities without transportation, logistics, and border issues. On the other hand, the capital market provides an effective balance mechanism with the banking industry; contributes to the strengthening of competition in the financial market; reduces costs of business financing; supports the improvement of capital allocation and distribution; facilitates price formation; and provides a further monitoring system for the economy.

The necessity of the capital market would be more apparent by considering its primary functions. The capital market has some tasks that can be conditionally divided into two groups: general market functions that are inherent in each market, and specific functions that distinguish the capital market from other markets. General market functions include commercial, price, information, and regulatory functions. The general market function allows participants of the capital market to generate revenue from their operations in a given market. The price function of the market provides the system and the process of price formation, their constant movement. The information function produces and brings to its participants market information about financial instruments, subjects, and permitted content of their relations. And lastly, the regulatory function of the market which creates rules of trade and participation in it, sets the procedure for resolving disputes between the parties, sets priorities, and controls the management of the market.

The specific functions of the capital market include insurance, redistribution, infrastructural, and investment functions: the insurance function assists the reduction of price and financial risks in transactions with financial instruments; the redistribution function provides reallocation of funds between branches and spheres of the economy, directing capital to important sectors and industries; the infrastructural function performs the creation of trade networks; and, lastly, the investment function provides alternative sources of investing to banks, brokers, dealer companies, and investment funds.

In the transition countries of the CIS, the full potential of the capital market is rarely used due to the fact that not all of the various functions of the capital market have developed at all. Consequently, the capital market cannot be considered as an alternative source of business financing to the banking sector. There is also a serious lack of the fulfillment of the capital market's investment, capital allocation and distribution, price formation, information, and regulatory functions. Conversely, the banking sector fulfills these functions by occupying this vacuum. The actual conditions under which the capital market functions perform, and their main causes in CIS countries will be the subject of the next subsection. 


\section{MATERIALS AND METHODS}

This research has been conducted using literature review and publication research, comparative analysis and empirical study, and other techniques, including historical, qualitative, and quantitative research. The consequent thesis relies on data from the reports and reviews of IOSCO, the World Bank, the OECD, the EBRD, the IMF, the ADB, and other international organizations and other specific research.

\section{RESULTS}

The research's ultimate goal is to ultimately contribute to the development of a fair and functioning market economy in CIS countries through the improvement of their respective capital markets. The analysis assumes that complex legal and institutional reforms will serve the development of the capital market and its effects on inclusive economic growth in the region.

It would be too naïve to assume that CIS countries' capital markets would flourish like those of the UK or the US. We found that several factors directly affect the development of the capital market in CIS countries. The country's economic development level, the legal system, and social features are core issues to consider designing CIS countries' capital markets. Ensuring a balanced approach in banking and capital market regulation, equal treating SOEs and POEs, applying market transparency, and implementing free-market principles instead of administrative ones promote a real competition on business financing.

\section{DISCUSSION}

\section{The necessity of capital market regulation in CIS countries}

This subsection considers the issue of why proper regulation is crucial for the further development of capital markets in CIS countries. According to the existing consensus a sound legal framework, property rights, shareholder protection, enforcement of contracts, and the rule of law are capable of attracting relatively higher investment levels and therefore have larger financial markets. Furthermore, regulation is necessary in ensuring company transparency that, in turn, is essential for investor protection and to inspire the confidence of market participants, especially investors, on the activity and behavior of managers and controlling shareholders. According to Professor Bernard Black, a country whose laws fail on this issue cannot develop an active capital market.

The necessity of regulation for the capital market is key since imbalances and crises in the financial sphere can become a dominant destabilizing factor for the economy of any country. The disruptive effects of the recent financial crisis patently demonstrate the necessity of appropriate regulation in the capital market for strengthening investors' protection, ensuring competition, and guaranteeing fairness in market relations not only at the national level but also within regional and global contexts. Thus, one of the main aims of capital market development reforms in CIS countries should be to take appropriate lessons from existing cases and not to repeat mistakes.

One of such lessons could be the most recent financial crisis, the roots of which go to the US financial and particularly the mortgage markets, and the consequences of which affected almost every country of the world. According to 'The Financial Crisis Inquiry Report' which was prepared by a special National Commission of the US, "scant regulation" was one of the main reasons that led to the full-blown crisis in 2008. Another point in the Commission's conclusion was that the financial crisis was avoidable, and it was the result of human action and inaction: "failures in financial regulation and supervision proved devastating to the stability of the nation's financial markets."

Therefore, regulation is necessary for capital markets, especially for emerging ones, for protecting investors against losses, for ensuring freedom and fairness of market relations, and for stimulating growth and development. Perhaps the most convincing argument proving the need for regulation of the capital market is the presence of developed regulatory structures of the capital market in so-called free-market countries that only theoretically heed Adam Smith's notion of the corrective 'invisible hand'. According to a prominent scholar in political economy - Ha-Joon Chang - there is no so-called 'free market' - every market has some rules.

The regulation of capital market relations is much more necessary in transition economies, such as CIS countries, where nascent capital market infrastructure cannot fulfill its regulatory and other functions; market participants are not professional, and a shadow, than the legal or conventional, market is developed. These specific features of transition economies make it necessary for there to be a proper regulatory framework for CIS capital markets particularly aimed at giving effect to the stabilizing, protecting, and stimulating functions of the capital market.

After clarifying the necessity and importance of regulation for capital market relations, the next issue to be considered in the following section is the nature of the institutional and regulatory framework of the capital market in CIS countries. 


\section{Development of institutional and legal bases of the Russian securities market 2.1. Overview of Russian capital market infrastructure}

Russia possesses the largest capital market and the most developed market infrastructure not only across the CIS but also across the entire post-soviet and satellite region. One of the main reasons for this is based on the model of the financial market applied in Russia. According to Golovnin, who conducted comprehensive research on the capital market infrastructure development in EAEC countries, Russia applied the Anglo-Saxon financial model, which is oriented towards the capital market, whereas Kazakhstan, Uzbekistan, and other CIS countries adopted the continental European model that is focused upon the banking system. However, this is only a structural characterization, given that the existing banking system of Russia as it has developed since the collapse of the USSR, with the high degree of state involvement in it, does not entirely fit within the conventional Anglo-Saxon model. That is the reason why other scholars characterize the Russian capital market as a mixed, polycentric, model, whereby commercial banks, the stock exchange, and other financial institutions participate simultaneously yet with a disparity of influence. The roots of such divergence are to be found in the transition history and privatization methods of the Russian experience, briefly discussed in the previous subsection.

The Russian capital market infrastructure is relatively developed in comparison to the other post-Soviet countries both in terms of financial instruments and institutions. Compared to other CIS countries, in the Russian capital market a maximum variety of financial instruments are traded, including shares, federal loan bonds, regional and corporate bonds, sovereign and corporate Eurobonds, depositary receipts, investment shares, mortgage participation certificates, and exchange investment funds. In 2016 variety of new bonds was launched which boosted market liquidity. In particular, the most short-term bonds, known as overnight bonds, issued 49 times in a year for a total of 1.4 trillion rubles (RUB). Another new type of bond - namely, Russian law-governed foreign currency bonds - appeared on the market as an alternative to borrowing from global markets. In 2016, three issuers offered foreign currency bonds worth a total of USD 1.4 billion. Moreover, the futures market of the Moscow stock exchange organizes trading with: futures contracts for indices (MICEX index, RTS index, RVI volatility index); futures on Russian and foreign shares, Eurobond Russia-30, currency pairs, interest rates; futures for oil and sugar; option contracts for some of these futures. No other CIS country can boast of trading in such variety of financial instruments, as Russia does.

Despite such established trading in a wide range of financial instruments, "the real investment potential of the stock market still fell short of the countries' need for financial resources", low public and investor confidence being the reason behind the departure of private investors from the capital market that consequently lead to the dominance of state and quasi-state institutional investors, including the Pension Fund, Sberbank, VTB, and other development institutions. This can explain the prominence of government securities in the Russian capital market, which represent the most advanced market means of public debt. However, such investments of budgetary funds are not entirely acceptable means from the viewpoint of market economy principles.

Stock exchanges play an essential role in the capital market infrastructure as they provide the primary platform for trading with securities at the national, regional, and global levels. In Russia, the Moscow Stock Exchange serves as such a central platform. It is included in the list of the largest exchanges of the world (the second for bonds, the third for the number of derivatives contracts, the twenty-fourth in terms of the volume of share trading). The main feature of the Moscow Stock Exchange is its multifunctional and consolidated character that is not present in other CIS countries, including Uzbekistan. Firstly, the Moscow Exchange Group manages the only multifunctional stock exchange in Russia for trading stocks, bonds, derivatives, currency, money market instruments and commodities. Secondly, its function is not limited only to the organization of securities trading. It also includes the central depository (namely, the National Settlement Depository), as well as the clearing center (namely, the Bank National Clearing Center), which performs the functions of the central counterparty in the markets, which allows the Moscow Exchange to provide customers with a full cycle of trading and post-trading services.

\subsection{Capital market regulatory structure in Russia}

The organizational structure of capital markets is one of their main institutional attributes. Hence why the effective functioning of the capital market is impossible without state regulation and supervision. In the last three decades, the Russian capital market organizational structure underwent several stages. The reforms on structuring the regulatory architecture of the capital market during this period can be broadly divided into three phases. In the first phase of changes (1993-2004) the Securities and Exchange Commission was established under the President of the Russian Federation (1993). In 1996 this Commission became the Federal Commission for the Capital market of the Russian Federation (FCSM), and further legislation that defined its legal status and authority was adopted.

In the second phase, which covered the period from 2004 to 2012, several structural reforms directed toward strengthening the legal status and powers of the regulator were carried out. In 2004 the FCSM was abolished and another authority - the Federal Service for Financial Markets - was established which took over the functions of control and supervision of the abolished FCSM and of other bodies. Further reforms were 
connected with the position of the regulator within government. The regulator`s name and status were changed several times since 1993; de jure the regulator was under the President of the Russian Federation. However, from 2004 it was transferred to the jurisdiction of the Prime Minister. In 2011 the Russian Federal Insurance Supervision Service annexed the Federal Service for Financial Markets.

The third phase of reforms was more crucial than the previous phases due to its form and content. It was connected with the idea of creating a mega-regulator in the financial sector as a part of reforms aimed at making Moscow an international financial center. The creation of a mega-regulator in Russia began to be actively debated in 2012 when the UK, whose capital is a principal global commercial center, shifted from the single regulator to a twin peaks approach. According to the vice-president of the Russian Bank Association, Yuriy Kormosh, the idea of creating a mega-regulator in Russia was first proposed by the British company Cadogan Financial in 1999. However, today the discussion on the creation of a mega-regulator in Russia is settled, given that since September 1, 2013 the Federal Financial Markets Service has been abolished and its powers transferred to the Bank of Russia.

Moreover, by March 3, 2014, the Financial Markets Service of the Bank of Russia was abolished about two years earlier than planned. The authority to regulate, control and supervise the financial markets, previously carried out by the Financial Markets Service was transferred to subdivisions of the Bank of Russia. Consequently, the Bank of Russia has become the state regulator in the capital market in Russia.

The Ministry of Finance possesses some residual limited powers to determine the procedure for the issuing of federal government securities, and is responsible for registering government, municipal and regional bonds, and bonds issued by insurance companies. Federal Antimonopoly Service of Russia is authorized to take measures to protect investor rights, and to oversee merger and acquisition deals concerning JSCs.

The Russian capital market regulatory structure is relatively developed in the sense of self-regulatory organizations activity. Currently, there are seven major self-regulatory organizations in the Russian capital market. They actively participate in establishing rules and standards; protecting members' interests; improving law enforcement practice, and raising public awareness.

\subsection{Origin and development of capital market legal basis in Russia}

The specifics of Russian capital market regulation are directly connected with the country's method of market economy transition and privatization reforms briefly discussed above. The shock therapy method of privatization and of creating a capital market overnight did not leave space for the elaboration and adoption of appropriate legal bases for those relations. Consequently, the emerging capital market had had to survive unaided by the fundamental laws concerning the capital market, JSCs, and the stock exchange. Instead, "market participants were forced to use outdated, Soviet-time Civil and Penal Codes and other laws" and some by-law acts that regulated dynamic capital market relations. According to the Chairman of the Russian Investor Protection Association, Dmitriy Vasiliev, the delay of the early legal reforms concerning the Russian capital market during 1991-1998 impacted on the character of the market and "allowed easy creation of so-called "financial pyramids." Gaps in legal regulation also caused the emergence of an oligarchs' class; an increase in corporate raiders practice; and other violations of shareholders' rights.

The law on the capital market was adopted in as late as 1996, after five years of intensive privatization reforms; after the almost complete distribution of state property among the Communist Party elite (nomenklatura) and officials to the "new Russians." One could compare it to the situation in Kazakhstan and Uzbekistan where the adoption of the first special laws (not by-laws) was as early as in the early 90s. Of course, one could reasonably argue that the adoption of laws alone when accompanied by weak institutions and poor enforcement practice does not change the situation much. Giving due attention to this viewpoint, it should be mentioned that the existence of exclusive legislation in the early stages of market relations suggests the presence of some concern about the fairness of relations, an attempt of ensuring investor protection, and of efforts on reducing systemic risk.

Despite the decent quality and level of and enforcement, currently Russia possesses most special laws that are necessary for modern capital market relations including, among others: the Federal Law on the Capital market; the Federal Law on Joint Stock Companies; the Federal Law on the Protection of Rights and Interests of Investors in the Capital market; the Federal Law on Banks and Banking Activity; the Federal Law on the Central Depository; the Federal Law on Investment Activities in the Russian Federation in the Form of Capital Investments; the Federal Law on the Specifics of the Issue and Circulation of State and Municipal Securities; the Federal Law on Clearing and Clearing Activities; the Federal Law on Organized Trading; the Federal Law on Investment Partnership; and the Federal Law on Central Bank of Russian Federation (Bank of Russia). In addition to these laws, regulation is also effected by bylaw acts on the part of the government, the President, and the central regulator - namely, the Central Bank of Russia.

Among the legislation mentioned above, the Law on the Capital market plays an important role in capital market regulation due to its rich content and coverage of the whole range of capital market relations, including securities issuance, their circulation, regulation, and participant responsibility/liability matters. Russian securities law is relatively modest compared to that of Kazakhstan and Uzbekistan. For instance, in the relevant legislation, the main issues - such as the legal regime of the security, the conception of the capital market; the activity of the 
accounting system entities, etc. - have not been completely resolved. According to Gabov, judicial practice in cases arising from disputes in the capital market - for example, discussions of owners with registrars and issuers - suggests that a market with such regulation does not give participants a fundamental thing: namely, the certainty and inviolability of their rights.

After the financial crisis of 2008 the government took seriously the need to improve its capital market legislation. Thus, with the aim of improving the regulation and development of the financial market for the medium- and long-term, the government approved the 'Strategy for the Development of the Financial Market of the Russian Federation for the Period to 2020' and presented the 'Plan of Measures for Creating an International Financial Center in the Russian Federation'.

\section{Development of institutional and legal bases of Kazakhstan capital market \\ 3.1. Overview of Kazakhstan capital market infrastructure}

The Kazakhstan capital market belongs to the most developed financial markets in the Central Asian region and one of the leading markets in the CIS. Along with the general features of CIS countries' capital markets (discussed in previous sections), there are some notable specifics concerning the formation of the Kazakhstan capital market infrastructure. Firstly, unlike other CIS countries, Kazakhstan has been attempting to diversify the supply side of its capital market. For instance, in 2012 Kazakhstan was the first in the post-Soviet region to launch Islamic bonds (Sukuk Al-Murabaha). Sixty-two percent of this issue went to Malaysian investors and the remaining thirty-eight percent went to the capital market of Kazakhstan.

Moreover, Kazakhstan issued 10- and 30-year Eurobonds for USD 4 billion. Even though the reason for issuing these bonds was to cover the deficit of the state budget, it was a serious step towards the global capital market. Consequently, such financial instruments have become a serious alternative to traditional bank lending due to their level of credit risk, interest rates, and terms.

Secondly, the involvement of the banking industry in the capital market relations of Kazakhstan is more active than in Russia. The fact that Kazakhstan Stock Exchange, which is the leading platform for securities trading, was founded by National Bank and another twenty-three leading commercial banks of Kazakhstan is illustrative of the substantial role of the banking industry in the formation of the capital market infrastructure. Bank participation is far-reaching and covers all relations of the market, including issuing a wide range of securities, acting as an investor, and rendering market intermediary services.

Thirdly, unlike Russia and other CIS countries, in Kazakhstan non-banking professional investment institutions are relatively developed. For instance, pension funds have an active role as investors, shareholders, and intermediaries in the capital market.

Fourthly, unlike Uzbekistan, and like Russia, the Kazakhstan stock exchange acts as a universal financial market, there is systematically organized trading in fields including the foreign currency market, the government capital market, the equity market and corporate bonds, the repo operations market, and in the derivatives market.

And fifthly, in 2016 Kazakhstan launched the International Financial Center (IFC) in Astana, which is based on English law principles and on the standards of the world's leading financial centers, and which is designed as a prototype of the Dubai IFC. The IFC supplements the existing capital market infrastructure with a new institution, namely, a Special Court that is outside the ordinary judicial system of Kazakhstan. It was proposed to improve the dispute resolution system of the capital market, which is one of the critical points of investor confidence in the market, to increase the scale of investment, and to ensure the integration of the Kazakhstan capital market with international markets.

\subsection{Capital market regulatory structure in Kazakhstan}

The capital market organizational structure in Kazakhstan has also faced several reforms until the establishment of the current mega-regulator system under the regulation of the National Bank of Kazakhstan. In the first stage of changes (1991-1994) as has been the case with the other countries compared, the Ministry of Finance was responsible for the regulation of the emerging capital market.

The development of market relations, increasing the quantity and quality of financial instruments and market participants, as well as the necessity of implementing international standards on capital market regulation, severely reformed the regulatory structure of the industry. As a result of these reforms in 1995, the National Commission on Securities was established as an independent body, which was the authorized body for capital market regulation in Kazakhstan until 2000.

In terms of the specifics concerning the participants in the Kazakhstan capital market, banks are the most dominant both in relation to stock issuance and circulation, and in influencing the future development of the regulatory regime. Thus, for the next five years the capital market regulator sat within the structure of the National Bank as a separate department.

From 2004 to 2011 the regulatory and supervisory functions were performed by the Agency of the Republic of Kazakhstan on Regulation and Supervision of the Financial Market and Financial Organizations (FSA) - an independent entity that reported directly to the President. During 2011-2013, the Committee for the 
Control and Supervision of the Financial Market and Financial Organizations (FSC) - then a subdivision of the National Bank - performed the supervisory and regulatory functions in the capital market of Kazakhstan.

In January 2014, by Presidential decree, the FSC was abolished and its departments were subsequently absorbed by the National Bank, which is accountable to the President, who, among other things, appoints its Chair (with the consent of Parliament) and his/her deputies. The President also approves the National Bank's structure, overall size of its staff, and its salary system. The law does not specify the conditions under which the National Bank Chairman and his/her deputies may be removed from office.

\subsection{Origin and development of capital market legal basis in Kazakhstan}

As mentioned above, Kazakhstan started to build a legal framework of its emerging capital market in parallel with its economic and institutional bases. Thus, the first Kazakhstan securities legislation appeared on 11 June 1991, namely, the Law of the Kazakh SSR On Circulation of Securities and Stock Exchange - a critical law for capital market regulation that determined initial norms on the status of both financial instruments and regulators. This act mainly focused on facilitating trade in securities, and it did not institute any effective control or sanctioning mechanisms. Due to the lack of proper control over the capital market it is unsurprising that several major financial scandals soon emerged. What is more, the Ministry of Finance had to issue a temporary instruction on licensing professional activities in the capital market following nine months from the adoption of this legislation. By this instruction, the Ministry of Finance authorized 1,460 individuals and 98 legal entities from 1992 to 1994.

In 1997 a new phase of property redistribution was launched that was characterized by the use of important schemes, such as legalized blurring of government shares, converting debts into securities, selling receivables, trust schemes, buying bills, and manipulating dividends on preferred shares. Also, the active participation of the state and escalating investor protection issues concerning the redistribution of the largest Kazakhstani companies resulted in strengthening the legal bases of investor protection. For instance, by the end of 1997, the Kazakh capital market had an expanded legislative base based on the provisions of the Civil Code of the Republic of Kazakhstan, which provided a set of measures to protect the interests of investors. The legal basis of the capital market was the Law on the Capital market of March 5, 1997, and some regulations issued under the above law by the Government of the Republic of Kazakhstan and the National Commission on Securities. For instance, the Law on Registration of Transactions with Securities in the Republic of Kazakhstan of 5 March 1997; the Law on Investment Funds in the Republic of Kazakhstan of March 6, 1997; and the Law on Pensions in the Republic of Kazakhstan of June 20, 1997.

Presently, the Law of the Republic of Kazakhstan on the Capital market of July 2, 2003 determines the basics of capital market regulation. It was adopted a month after the Law on Joint Stock Companies was approved on 13 May 2003, which represents the beginning of a more qualitative approach to regulation. The Securities Law regulates social relations arising in the process of issuing, placing, circulating and redeeming equity securities and other financial instruments. The specifics of the creation and activities of capital market entities, determine the procedure for regulation, control and supervision of the capital market in order to ensure the safe, open and effective functioning of the capital market, protection of the rights of investors and holders of securities, fair competition of participants in the capital market. The last reforms on the improvement of capital market regulation suggest a strong willingness on the part of government to boost the market and investment through financial instruments and the capital market. For instance, the state initiative to establish a Regional Financial Center in Almaty aimed at the development of the capital market, its integration with international capital markets, attracting investments into the economy of Kazakhstan through capital market and through the access of foreign issuers into the particular trading floor of the financial center, all encourage the improvement of the situation. However, some scholars are skeptical as they consider the reality of attracting international portfolio investment through the Regional Financial Center of Almaty as discourage medium-sized domestic enterprises for involving access into the capital market. Instead, they propose that the most effective financing and the best government support for the market is the fostering of a competitive environment with equal conditions. Honest competition leads to more efficient sector development. Giving due attention to the government initiative, the present author also supports the approach of fostering a competitive environment in the financial market.

\section{Development of institutional and legal bases of the Uzbekistan capital market 4.1. Overview of Uzbekistan capital market infrastructure}

Generally, the specifics of the capital market infrastructure of CIS countries reviewed are also present in Uzbekistan's capital market institutions. However, several features should be taken into account in proposing recommendations on the improvement of the current situation of the market. Firstly, financial instruments in Uzbekistan's equity and state capital markets are relatively developed rather than its corporate bonds and derivatives markets. The dominance of the equity market mainly derives from the privatization method adopted, based on which state enterprises were restructured as JSCs. Compared to the Kazakhstan and Russian capital market, there is almost no derivatives market in Uzbekistan. The reasons for the underdevelopment of the 
derivatives market in Uzbekistan is connected both with the systemic and structural drawbacks of the national capital market, and the features of the derivative itself.

Secondly, the leading platform for securities trading - namely, the Tashkent Stock exchange (TSE) - is not the multifunctional financial institution as is the case with those of Russia or Kazakhstan. The TSE organizes trading only with shares, state and corporate bonds, deposit certificates, and derivatives. Trading with commodities, and foreign currency held by Tashkent Commodity Exchange, and Uzbekistan state Currency Exchange respectively. For Uzbekistan, the consolidated exchange is characterized in the initial stage of development when in 1991 a stock department was formed within the Tashkent Exchange as the first capital market institution. In the opinion of the present author, the high level of specialization of different exchanges is a sign of a developed exchange system in the country. From this viewpoint, Uzbekistan's experience on establishment of separate trading platforms with different types of product (stocks, commodity, foreign currency, agricultural, etc.) could be a good example concerning the organization and regulation of exchange activity in the CIS region.

Thirdly, the state regulator for the capital market is not combined with the banking regulator, as is the case in Russia from 2013, and Kazakhstan from 2014, where the central bank is responsible for the regulation of the entire financial system, including the banking industry, capital markets, insurance, and the capital market. The state regulator's status was the object of separate research in which the present author had been involved, which included a comparative analysis of the state regulatory regimes of the capital markets of Russia, Uzbekistan, and Japan. The conclusions of that research indicated that it would be appropriate to implement in Uzbekistan a unified model of state capital market regulator under the authority of its Central Bank.

And fourthly, Uzbekistan's capital market has a relatively modest index of trading stocks in foreign currency (FC trade/FTC), which shows the openness of the market to foreign investors and access of national companies to global financial markets. The underdevelopment of the FCT market, while not an excellent feature, was actually one of the main reasons that Uzbekistan's loss was minimized during the last major crisis - namely, the global financial crisis of 2008. However, in general, this is a critical factor for fostering foreign investment flows into the national capital market, and opening access for domestic companies in global financial markets.

\subsection{Capital market regulatory structure in Uzbekistan}

The experience of Uzbekistan in establishing its state capital market regulator has been under way since 1991 when the country began gradual reforms towards building a market economy. These reforms could be divided into three stages. In the first stage, attention was mainly paid to creating the legal and institutional basis for capital market regulation through the adoption of legislation and the establishment of appropriate market institutions. In 1991 the legal basis of exchanges activity was provided by the Exchanges Council as a coordinating body for exchange activities. The Council was formed from the chairpersons of the exchanges operating in Uzbekistan.

In the second stage, the gradual reforms mostly focused on increasing the quality of the regulatory structure. For instance, the Presidential Decree on Additional Measures to Develop Capital market, adopted on September 7, 1995, introduced a series of fundamental standards directed at the state regulation of the capital market. According to that Decree, the State Securities and Exchange Commission (SSEC) was formed under the Ministry of Finance of Uzbekistan. Its purposes included the implementation of state policy on the development, deepening and broadening of the capital market, the removal of existing barriers to its further development, as well as the protection of investor and shareholder rights and interests.

The SSEC had to very closely cooperate with the State Committee of Uzbekistan for State Property Management (SPC) - i.e., the authorized body for the privatization process. The reason for this cooperation was securitization, which was the primary method of privatization. The Presidential Decree on the Formation of the Center for Coordination and Control over the Capital market under the State Property Committee of Uzbekistan of March 26, 1996, strengthened the legal framework for such cooperation. According to the Decree, the aim of establishing the Center for Coordination and Control of Capital market under the SPC (CSM), instead of abolished SSEC under the Ministry of Finance, was to improve the functioning and state regulation of the capital market, to coordinate the activities of its members, and to ensure the protection of investor rights and interests. Moreover, this act determined the legal status of the CSM as the authorized state body regulating the capital market. The Resolution (Charter) of the CSM was approved by the Government's Resolution on Organization of the Center for Coordination and Control over the Capital market under the State Property Committee of Uzbekistan of March 30, 1996. Based on this Resolution governmental bodies and capital market participants defined one of the main objectives of the CSM was to oversee the implementation of securities legislation.

In the third stage of reforms, which are ongoing, the structure of the capital market regulation was improved. These improvements included the further privatization of state assets and widening the range of private property as the basis of a market economy, the improvement of antimonopoly regulation and the fostering of a real competitive environment, the accelerated development of the capital market (especially the secondary one), and the improvement of corporate governance. A Presidential Decree of November 13, 2012, created the State 
Committee of Uzbekistan for Privatization De-monopolization and Development of Competition by the abrogated SPC and State Committee of Uzbekistan for De-monopolization and Development of Competition.

However, these reforms toward a unified regulation of state property management, the capital market, and antimonopoly regulation gave rise to fundamental problems including conflicts of interest. Some of these have been solved, mainly through measures on the elimination of conflicts of interest between the SPC, which is the main authorized body on managing state shares in joint stock companies, and the CSM, which is under the jurisdiction of the SPC. Under a subsequent government Resolution, the new organizational structure of the SPC was approved, the Center for Management of State Assets under the SPC was created, and the name of the capital market regulator was changed to the 'Center on Coordination and Development of the Capital market' (CSM).

After these latest reforms, the securities regulatory body is still under the jurisdiction of the SPC. The difference from the previous structure is that managing state assets and regulating securities are currently the responsibility of two separate Centers in the formation of the SPC. This theoretically and partly solved the conflicts of interest mentioned above. However, due to both Centers being under the jurisdiction of the SPC, such problems may recur during their activities that could interfere in the independent operation of the capital market regulator.

\subsection{Origin and development of legal basis in Uzbekistan}

The Law on Exchanges and Exchange Activity was amongst the first pieces of legislation to determine, clarify, and guarantee the activity of the leading institutions of the capital market - i.e., the exchanges in Uzbekistan. As mentioned by one the prominent scholars of Uzbekistan specializing in capital market, Igor Butikov, at that time there was an urgent necessity for the adoption of this law. In the early 90s, in Uzbekistan, as was the case with other republics of the former USSR, the exchange movement had gained momentum. By the summer of 1992, there were already 36 different stock exchanges in the republic. The government was alarmed by the fact that the number of exchanges was growing at an explosive pace, and since exchanges are in the sphere of circulation, economic institutions such as exchanges were necessary to regulate such transactions.

Meanwhile, the country, particularly at that time, needed the production of consumer goods, food, etc. that is it needed the development of its productive base. Since up to that point there had been no law on stock exchanges as such, any organization that registered itself as an exchange could receive significant revenues, producing nothing but the registration of various kinds of contracts. Therefore, in July 1992, the Supreme Council of the Republic of Uzbekistan adopted the Law on Exchanges and Exchange Activities, in which the status and basic norms for the activity of stock exchanges and stock departments of commodity exchanges were first determined. The main requirements for the exchanges were as follows: the statutory fund was to be at least 50 million rubles, the founders of exchanges could not be state bodies, and the stock exchanges themselves were prohibited from establishing and investing money in any business organizations whose activities were not connected to the maintenance of exchange trades. As a result, by 1993 there were only two exchanges left in the republic: namely, the 'Tashkent' Exchange and the 'Uzbekistan' Exchange i.e., the Republic's Agro-industrial Exchange.

Another important act of that year was the adoption of the Law on Securities and Stock Exchanges, which provided a definition of securities, its main types (shares, bonds, treasury bonds, deposit certificates, exchange bills), provided for the regulation of their issuance and circulation, established the legal status of stock exchanges and market participants, and provided for the supervision of the capital market. This was the first law determining the legal basis for regulating the capital market and thus laying the foundations for its development in Uzbekistan. The Law on Securities and Stock Exchanges was enforced until 2008, when, further to far-reaching reforms of the securities legislation, the new Law on Capital market was adopted.

So, in the first stage of the development of the country's capital market (1990-1993), necessary legislation was adopted to determine the status of private property, including securities, market participants (issuers, investors, trade organizers, and intermediaries), and the framework of regulation of the capital market.

The strengthening of market infrastructure, increasing the number of participants, and strengthening state regulation were key features of the second stage of the development of regulation for the capital market of Uzbekistan. Thus, in 1994 the first, and, currently, the sole, stock exchange - namely, the Tashkent Stock Exchange (of the Republic) - was created as an organized market for the circulation of securities. In that year 13 broker firms were accredited, and exchange trade circulation was 30 million USSs. Unsurprisingly, without an authorized regulatory body of the capital market, it was difficult to regulate and coordinate the whole capital market, hence why establishing the Center for Coordination and Control of Capital market under the State Property Management Committee of the Republic of Uzbekistan on March 26, 1996, represents the beginning of a new stage in the development of securities regulation in Uzbekistan.

During the second stage of privatization, several new JSCs appeared almost daily. On April 25, 1996, the Law on Joint Stock Companies and the Protection of Shareholder Rights was adopted. This law was the first to create the legal framework for corporate governance in Uzbekistan. The same day a further piece of key legislation concerning securities regulation was adopted - namely, the Law on the Mechanism of Operation of 
Capital markets. This legislation was relevant because it covered all aspects of capital market relations and their regulation. Notably, the law provided: for the clarification of the concept of the capital market and investment institutions, the operation and regulation of the capital market, the disclosure of information rules, and for the clarification of the responsibilities of capital market participants. At that time one of the foremost institutions of the capital market - namely, the depository system - was complicated, and the depositories have insufficient links to each other. The Law on Depository Activities at Capital markets of August 29, 1998, reorganized the depository system into a two-tier order: the State Central Securities Depository and second-level depositories.

After laying down the necessary legislation and the capital market infrastructure, subsequent reforms in securities regulation aimed at strengthening international relations and the protection of investors' rights in the capital market. Based on this reform on January 12, 1998, Uzbekistan's authorized regulatory body for the capital market joined the International Organization of Securities Commissions (IOSCO). Taking into account the active participation of foreign investors in the capital market, on August 30, 2001, the Law on the Protection of Investors' Rights at Capital markets was adopted. That year exchange turnover stood at 8.0 billion UZSs, including less than USD 1 million in the foreign currency platform. In September 2001 the Tashkent Exchange joined the International Association of Exchanges of CIS countries. As a result of these reforms, the EBRD's Capital markets Legislation Assessment in 2004 indicated that Uzbekistan's legislation was in 'medium compliance' with IOSCO principles.

Such relatively high international appraisal and other existing issues provided the impetus for further reforms aimed at improving the securities legislation and regulation. Various special teams in the Cabinet of Ministers, Ministry of Finance, Central Bank, and the Centre for Coordination and Control of Capital market were created to study the reasons and to explore solutions for existing problems in the field. Based on the intensive work and joint efforts of academics, practitioners, and experts, a draft Capital market Development Program for 2006-2007 was prepared which very soon was approved by way of Presidential Resolution on Measures on Further Capital market Development dated 27 September 2006, No. PP-475. The preparation and adoption of this program marked a new stage in the event of capital market legislation and regulation.

The second part of the Capital market Development Program focused on accelerating the development and expansion of the secondary capital market, and had the most significant tasks among the other elements of the Program. The first of these tasks was the elaboration of a law on the capital market by the fourth quarter of 2006. The draft of the bill was prepared and was passed by the Legislative Chamber (i.e., the lower house of parliament) on February 13, 2008. The Law on the Capital market came into force on July 23, 2008, following approval by the Senate (i.e., the upper house of parliament) on June 27, 2008, and signature by the President on July 22, 2008.

In general, the adoption of the Law on the Capital market has brought the country closer to the implementation of the recommendations of the Group of Thirty (G30) concerning both the dematerialization of securities and the concentration of accounting for securities in a single center. In this way, another significant step was taken to integrate the domestic capital market into global capital markets. According to this legislation, shares should be issued in a non-cash form - namely, in the form of entries in deposit accounts. The legislation further established the rule that the depositary accounting for stocks and corporate bonds is carried out only by depositaries. Depositary accounting of securities by the Central Depository is considered as the maintenance of the owners' list.

With the adoption of the Law on the Capital market four existing laws were unified, namely: the Law on Exchanges and Exchange Activity; the Law on Securities and Stock Exchanges; the Law on the Mechanism of Operation of Capital markets; and the Law on Depository Activities at Capital markets. It was not just a simple merger of the four acts. It consisted of double-checking all norms of actual acts to prevent duplication and normative conflicts; it provided improvements for regulators and convenience for participants through a single primary source, and sought to address existing problems and to the norms in rapidly growing relations consistent.

Substantively, the new law introduced some innovations, which promoted better regulation of the capital market. For instance, the restrictions on combining different forms of professional activity in the capital market were abolished. The disclosure information system for small business entities was liberalized. All kinds of shares were changed into electronic form. The securities register system was improved, a centralized digital database was created, and the Central Depository of Securities was nominated as a Central Register. A new type of professional activity in the capital market - transfer-agency - was introduced, and the system of central regulators was improved to better implement consistent state regulatory policy in the capital market. Principally, the legislation determined that the authorized state body for the provision of the capital market should regulate all security issuance, distribution, and circulation independently, except state securities, the regulation of which would be conducted together with the Central Bank and the Ministry of Finance.

In May 2014 the Law on Joint Stock Companies and Protection of Shareholder Rights was adopted in a new edition. The aim of this revised legislation was to increase the legal protection of shareholders, especially minority shareholders, to enhance the role and importance of management and control bodies of joint stock companies, to further develop the corporate governance system, and to ensure information transparency of JSC 
activities for shareholders and potential investors. A year later, in 2015, the Law on the Capital market was adopted in a revised/amended form to simplify the procedures related to the issuance of securities, including new financial instruments. This legislation also introduced the conclusion of transactions with securities through the widespread introduction of modern electronic technologies, as well as the revision of the requirements for professional activities in the capital market, including clarification of liability for violation of market legislation. The law enhanced the range of capital market objects and subjects. For instance, Article 3 of the revised legislation is supplemented by such concepts as 'depositary receipts', 'infrastructure bonds', 'clearing', 'market maker', and 'netting'.

The securities law from 2015 presented several regulatory initiatives, for instance, according to the law, securities-trading organizers should establish a guarantee fund for the compensation of possible losses to investors (cf., Article 23). The depositary activity is abolished as a separate professional activity (cf., Article 24), and its functions transferred to the investment intermediary (cf., Article 26). Furthermore, under this legislation, Uzbekistan National Bank is given the exclusive right to make cash payments on the transactions made in the organized markets (cf., Article 33), and the Central Depositary is empowered to assign securities with international codes (e.g., ISIN / CFI) (cf., Article 39).

What is more, this legislation also represented a shift towards taxation of incomes from securities transactions. According to Article 16, it is the seller (except issuers) who must pay to the state a fee of $0.01 \%$ of the transaction value. However, the income/profit of the seller, including non-residents of Uzbekistan, under the transaction, is not subject to corporate income tax or personal income tax. The new law establishes that the market maker is exempted from payment of fees and other debts to the Stock Exchange, Central Depository, and to the Uzbekistan National Bank where transactions are made in the stock exchange to maintain the level of prices, supply, and demand of securities (cf., Article 39).

Significant changes in the types of professional activities in the capital market, (namely, under Article 24 of the Law on the Capital market), such activities are carried out as: an investment intermediary; the investment adviser; investment fund; trust manager of investment assets; transfer agent; and/or organizer of over-the-counter securities trading. The depositary and the clearing institution as independent types of activities are abolished, while according to Article 26 of the revised legislation, the investment intermediary is required to keep a record of the securities and monetary funds of each customer, and to carry out transactions with securities by the contract concluded with the client.

\section{Development level and problems of capital market in CIS countries \\ 5.1. Development level of CIS countries' capital market}

Currently, the capital markets of CIS members are facing a range of institutional and legal problems that hinder their further development and integration with regional and global markets. According to the review of the transition experience of Russia, Kazakhstan, and Uzbekistan in previous sections of the present thesis, reform failure in CIS countries had much to do with institutional and legal factors. Also, despite almost three decades of changes, these factors remain the key issues for the implementation of market economy principles in CIS countries.

Today's general problem for all CIS countries' capital markets is the absence of a mechanism to ensure the complete realization of the potential of capital markets at the level of the national, regional, and global economy. Particularly, currently, the capital markets of CIS countries cannot be considered as providing a real competitive alternative source of business financing, an alternative system of mobilizing savings and allocations, an effective method of ensuring corporate governance and transparency of companies, and a potential way to attract foreign investors.

Statistics and the overview of capital market activity in the countries under review helps one to better understand the current situation. In the specific literature market capitalization over GDP, trade volumes, and some listed companies are used as leading indicators of capital market development.

Capital market capitalization is usually described as a percentile value /portion of GDP and shows the capital market size relative to the size of the entire economy. However, high capital market capitalization rates do not necessarily mean that the capital market is dynamic, especially in oligopolistic markets such as those of CIS countries. Capital market capitalization in Russia, Kazakhstan, and Uzbekistan are quite moderate compared to developed markets figures. For instance, in 2015 market capitalization of listed domestic companies in Russia stood at $29 \%$ (c. 622 billion USD) of its GDP, and in Kazakhstan it stood at 19\% (c. 40 billion USD). In Uzbekistan World Bank analysis shows $4.1 \%$ in 2006 (c. 715 million USD). According to the latest figures found in the ADB research paper from 2013 that relates to Uzbekistan capital market capitalization information for 2007-2011, the average rate of market capitalization in Uzbekistan stood at about $10 \%$ of its GDP (cf., Table 2). 
Table 2. Capital market capitalization in \% of GDP

\begin{tabular}{|l|l|l|l|l|l|l|l|l|l|l|}
\hline & 2006 & 2007 & 2008 & 2009 & 2010 & 2011 & 2012 & 2013 & 2014 & 2015 \\
\hline Russia & n/a & 116 & 24 & 70 & 66 & 42 & 43 & 37 & 22 & 29 \\
\hline Kazakhstan & 54 & 39 & 23 & 50 & 41 & 23 & 12 & 11 & 11 & 19 \\
\hline Uzbekistan & 4 & 8.8 & 10.4 & 7.30 & 9.4 & 9.7 & n/a & n/a & n/a & n/a \\
\hline
\end{tabular}

Source: The figures for Russia and Kazakhstan are based on World Bank Database (Market Capitalization of Listed Companies, \% of GDP 2006-2015).

The figures for Uzbekistan for 2006 are based on World Bank Database; for 2007 - 2011 is based on the ADB Country Assessment of Uzbekistan, 2013.

Another leading indicator for assessing capital market activity is the trade volume versus GDP (Table 3 ). It shows the value of shares traded is the total number of shares traded, multiplied by their respective matching prices. In 2015 capital market trade volume in Russia was $8.5 \%$ of its GDP; in Kazakhstan 1.4\%, and in Uzbekistan according to the latest available data from 2011 the trade volume of stocks comprised just $0.1 \%$ (about USD 118.7 million (c. SUM 213.1 billion)) of its GDP.

To conclude, there is still some space in the economy of CIS countries for trading with securities. In the largest economy of the region, securities trading does not reach even $10 \%$, in others, this index represents around $1 \%$ of GDP, which suggests significant underdevelopment of the securities industry as a business activity. At the same time, it provides a focal point for further development reforms and for fostering investment activity through this area of the market economy.

\section{Table 3. Capital market trade volume in \% of GDP}

\begin{tabular}{|l|l|l|l|l|l|l|l|l|l|}
\hline & 2007 & 2008 & 2009 & 2010 & 2011 & 2012 & 2013 & 2014 & 2015 \\
\hline Russia & 46 & 31 & 68 & 65 & 29 & 18 & 13 & 14 & 8.5 \\
\hline Kazakhstan & 8,5 & 2,9 & 3,7 & 1,3 & 0,6 & 0,7 & 0,3 & 0,5 & 1.4 \\
\hline Uzbekistan & 0.4 & 0.3 & 0.02 & 0.09 & 0.1 & 0.08 & 0.04 & 0.04 & 0.05 \\
\hline
\end{tabular}

Source: The figures for Russia and Kazakhstan are based on the World Bank Database (Stocks traded, total value (\% of GDP) 2007-2015);

The figures for Uzbekistan in 2007-2011 are based on the World Bank Database. NB., for

2012-2015 the figures are based on this author's calculations in turn based on data found at: uzse.uz; stat.uz; and cbu.uz.

The next important indicator as to the potential of the supply side of the capital market is the number of listed companies (Table 4.), including foreign companies, which are exclusively listed, and which have shares listed on an exchange. A higher number means that more companies use equity financing in their business. This indicator does not include market professionals, such as investment funds, unit trusts, and companies whose only business goal is to hold shares of other listed companies, such as holding companies and investment companies, regardless of their legal status.

According to the available data, among the countries examined in the present thesis, the highest index is that of the Russian market with an average of 250 listed companies. Despite the lowest level of capital market turnover and rate of market capitalization, there are almost 200 listed companies in Uzbekistan's capital market. A considerable amount of JSC stocks are not listed in the stock exchange, and these are traded in over-the-counter (OTC) markets. For instance, in 2008 there were only 19 listed companies out of $1800 \mathrm{JSCs}$; 20 companies out of 1781 JSCs in 2009; in 2011100 listed companies out of 1309 JSCs; in 2014 only 138 companies were listed out of 1090 JSCs. Lastly, concerning Kazakhstan, market analysis suggests a modest ranking concerning listed companies, with around 85 companies, despite the relatively active market turnover, which suggests a relatively high level of ownership concentration.

Table 5. Listed companies

\begin{tabular}{|l|l|l|l|l|l|l|l|l|l|l|}
\hline & 2007 & 2008 & 2009 & 2010 & 2011 & 2012 & 2013 & 2014 & 2015 & 2016 \\
\hline Russia & 328 & 314 & 279 & 345 & 327 & 276 & 276 & 266 & 251 & 242 \\
\hline Kazakhstan & 90 & 74 & 69 & 60 & 63 & 74 & 80 & 77 & 78 & 85 \\
\hline Uzbekistan & 114 & 19 & 20 & 152 & 100 & 130 & 138 & 138 & 261 & 191 \\
\hline
\end{tabular}

Source: The figures for Russia and Kazakhstan are based on the World Bank Database (Listed domestic companies, total 2007-2016).

The figures for Uzbekistan are derived from various sources: namely, for 2007 and 2008 the figures are based on the World Bank Database; for 2010-2012 they are from Almanac Uzbekistan, 2013; and the figures for the rest are taken from uzse.uz.

The listed companies' indicator highlights the oligopolistic character of the capital markets and the ownership concentration level of the economy for the countries under review. Furthermore, it also reveals the 
unrealized potential of capital markets that once realized through legal and institutional reforms could serve for the increase of investments into the economy and for the development of the country. However, at present, the capital markets of the CIS countries under review is in a state of underdevelopment, as the figures presented in the foregoing so abundantly suggest; they have yet to attract, and become the locomotive of, significant investments into the economy. The next task of the present thesis is to consider the significant underperformance of the capital markets of the CIS countries under review, to try to establish its causes, and to explore appropriate solutions.

\subsection{CMD Problems in CIS countries}

In previous sections, there were brief analyses of the origins and development of the capital markets in the three CIS countries under review, and there were attempts to outline the current level of their performance. According to the statistics mentioned in the foregoing, CIS capital markets exhibit modest levels of development. There are several factors that directly and indirectly influence the development of capital markets at the national, regional, and global level. These include economic, political, social, cultural, institutional, and legal factors. This research primarily focuses on the institutional and regulatory problems due to their nature and influence on the further development of capital markets in CIS countries. As shown in the earlier analysis and the discussion on the different transition 'puzzles' of CIS countries, the institutional and legal context is essential for building an efficient capital market. Respectively, to better understand the problems of capital market development (CMD) in CIS countries, these were categorized into two groups: namely, structural and regulatory.

Structural pertain to systemic and institutional issues that could be taken into account during the design of reforms. Particularly in this research, the following institutional problems are tackled: the oligopolistic nature of the market, the lack of competition in the financial services sector, and the significant role of the state both in regulation and business.

The oligopolistic nature of the market refers to the structure of the economy as a whole, and to the company ownership structure, in particular. In the structure of economics, it means dependence of the economy on few sectors, and the absence of, or insufficient, diversification of market economy sectors. This feature could be seen in every studied country, for instance, in Russia, capital markets are mainly dependent on oil and energy sector companies, in Kazakhstan oil companies and banks, and in Uzbekistan banks and natural resource-related companies. Oligopoly at the company level means a high concentration of shares within a limited number of shareholders. High concentration of shares and a limited number of shareholders cause the appearance of scarcity in the securities, which negatively affects the demand and supply balance of the market. Also, this kind of ownership structure of the company undermines the protection of minority shareholders' rights, and hinders access of new investors to the market.

Another structural feature of the capital markets of the CIS countries under review, which is indirectly connected with the oligopolistic nature of the market, is the lack of real competition in the financial services industry. In this regard, three types of competition are discussed below, namely: competition between the banking industry and capital market, primarily in accumulating funds and business financing, competition within the capital market, and competition between conventional forms financing (bank and capital market) and quasi-legal form of funding of (shadow lending and borrowing mechanisms).

The competition between the bank and the capital market is the most significant for the present research, hence why this issue is analyzed in more detail in chapter four. The present section is limited to relying on some basic statistics to hint at the scale of the problem. In CIS countries a substantial part of the accumulated and distributed financial resources is accounted for the banking industry, in comparison with the capital market. For instance, in Uzbekistan, as of April 1, 2017, total volume of bank loans directed to the real sector of the economy was in excess of 57.3 trillion UZS, while in 2016 the amount of Tashkent stock exchange transactions had only been 299.8 billion UZS. In Russia, the volume of bank credits in 2016 was 17 trillion rubles, in contrast, the capital market turnover was 9.2 trillion rubles. In Kazakhstan the volume of bank credits to the economy KZT 12.9 trillion in 2016, while transaction volume with shares in the same year was KZT around 3.9 trillion. There are several factors behind high divergence in the roles of the banking and the capital markets in business financing, including the financial structure, legal system, and the regulatory framework. However, the regulatory framework factor seems to be the most influential in terms of cause and potential for solutions.

Today in CIS countries real competition is necessary not only between the banking sector and the capital market but also within capital market institutions as competition is scarce. For instance, in Uzbekistan, despite the existence of three organized trading platforms, around 98 percent of the whole trading volume belongs to the Tashkent Stock Exchange. The other trading systems, namely, the Inter-Bank trading system (MTS) and the Electronic OTC trading system ('Elsis-Savdo') are limited to minor shares. The Tashkent Stock Exchange is the leading securities trading platform and the only corporate securities exchange. Also in Russia, there is a similar situation as the Moscow Stock Exchange became a leading platform for trading with securities after the merging of two major Russian exchange groups - namely, the MICEX Group (founded in 1992) and the RTS Group 
(founded in 1995) - in 2011. The Kazakhstan Stock Exchange is the leading trading platform in Kazakhstan. Weak competition among stock exchanges in CIS countries is one of the main factors of the underdevelopment of the capital market in these jurisdictions.

And lastly, the third issue connected with competition in fund accumulation and business financing is the so-called 'street funding'. In transition countries such as those of the CIS, there is a significant share of the shadow economy that is directly reflected in the financial services market. Particularly, alongside with bank credits and the capital market, there is another casual source, the so-called 'borrowing from the street' practice. It means borrowing from individuals, usually in a foreign currency and under higher interest rates than the capital market and even banks. From the outside, it looks like normal private lend-borrowing relations, but its nature and scale of this phenomenon is beyond the content of an ordinary consumer loan and it already covers a significant part of entrepreneurs. Among the countries under review, this phenomenon is most developed in Uzbekistan. Unfortunately, there are no official data or statistics on this issue, but merely observing business activity in Uzbekistan and the existence of a double and triple accounting system in major part of business entities prove the role of such 'quasi-legal' loans in the financial services industry of the country. One of the reasons that such 'quasi-legal' loan practices are thriving is connected to problems concerning foreign currency exchange; until recently, entrepreneurs, especially small- and medium-sized businesses (SMBs), had difficulty in taking credit from banks in foreign currency; and there was a significant difference between official, real, and exchange rates of foreign currency exchange. For business entities that usually import goods, it was easier and cheaper to borrow money from the 'street'. The fact of the existence of a shadow lending and borrowing system in CIS countries confirms that both the banking system and the capital market cannot meet the financial necessities of business, which, consequently, forces entrepreneurs to seek funds beyond the banking and capital market industry. This hugely impacts the regulatory framework both in terms of the causes and possible solutions to this problem. If CMD reforms directed to legalize this kind of 'quasi-legal' practice and convert this to banking and capital market activity, it can be useful both to the state, and to business. State benefits from such reform at least by increasing investor confidence in the financial system, the inflow of investments, and additional taxes. The legalization of shadow mechanisms of business financing gives legal guarantees to businesses, relatively affordable funds, and a chance for growth.

Also, the last structural feature of the capital markets of the CIS countries under review, to be covered in this research, is the significant role of the state as regulator and as a key participant. The level of state participation in capital market relations provides fertile ground for the assessment of the quality of implementation of market principles in the country. Today in CIS countries the state actively participates in capital market relations through its SOEs and banks that issue, own and manage various securities, and render intermediary services. Most importantly, the state sets the rules, regulates market relations through the authorized body, and is responsible for the fairness of dispute resolution. All CIS countries exhibit strict state regulation of the market through state regulators rather than through self-regulatory organizations. A high degree of direct and indirect state participation in capital market relations in CIS countries is a sign of administrative principles prevailing over market principles despite the almost three decades of market transition reforms. In Russia, Kazakhstan, and Uzbekistan, the state actively participates in the market through SOEs and banks. For instance, in Uzbekistan, around 70 percent of capital market turnover belongs to banks and their financial instruments, while approximately 60 percent of the banking industry belongs to the state. 20 percent (regarding the remaining 30 percent) of capital market turnover belongs to SOEs or companies with state assets. Initial Public Offerings (IPOs) and securities issues are usually performed on administrative decisions, instead of on market demand and supply principles. The stock exchange mainly hosts equity and secondary market transactions with shares of SOEs. In most cases, government agencies decide who can buy and sell shares and at what prices, and it is often impossible to locate accurate financial reports for traded companies. The situation in Russia and Kazakhstan is very similar.

Concerning structural problems, a lack of competition (between the banking industry and the capital market; as well as within capital market institutions) and the role of state (both in private and public relations) are key issues on which this research focuses, and the theoretical basis of these two issues will be analyzed in the next two chapters. The oligopolistic feature of CIS countries capital market will be taken into account during the exploration of solutions as a framework, due to its systemic character. The primary aim of this research is the exploration of appropriate solutions to the structural problems through legal and regulatory reforms. For achieving this task, below follows a brief exposition of the regulatory issues of capital market development in CIS countries in the example of Russia, Kazakhstan, and Uzbekistan.

The regulatory problems of capital market development in CIS countries are mostly connected with the drafting, adoption, and implementation of mandatory rules that are directed to the regulation of relations in this area. The content, form, and methods of enforcement of the law are the main issues of this cluster of problems. Unfortunately, it is outside the scope of this research to cover all the regulatory aspects of capital market development in CIS countries. Hence why the review is limited to the range of subjects who can issue securities, market access issues, and the range of securities that could be released by subjects. 
As for the securities issuer subjects, among the compared countries only in Uzbekistan, its scope is limited to JSCs and state bodies. In Russia and in Kazakhstan, the range of entities that has the right to issue securities is much broader and includes JSCs, LLC, partnerships, pension funds, and other objects. Today in Uzbekistan 80 percent of existing companies were established in the form of LLC. The number of JSCs is decreasing annually, and most of them are state-owned or with significant state shares, and less than one-third of existing JSCs are listed in the Tashkent Stock Exchange. To further develop the potential of capital markets in business financing, company law reform should be carried out to expand the range of companies that has the right to issue securities and involve funds from the capital market. There are several LLCs that are much bigger than JSCs. Even state participated companies are founded in the form of LLC. Complicated disclosure information mechanisms and various inspection system of JSCs makes this form of company unpopular/unfavorable to business representatives. Restrictions on the issuance of securities only by JSCs make the market passive and limits access to its financial resources.

The next issue on increasing the share of the capital market in business financing is connected with the access to the market by investors. Currently, Russia and Kazakhstan completed several reforms on opening their capital market to investors and have created opportunities for purchasing their securities on global markets. Unfortunately, in the case of Uzbekistan there is still a lack of reforms in both the national and global market context. For the domestic market until September 2017 because of the foreign currency exchange problems, the share of foreign investors was less than 10 percent of total trade volume. As for entering global markets, until now Uzbekistan has never seriously considered this issue.

Another issue connected to boosting the business financing potential of the capital market is improving the legal basis for diversifying the types of securities circulated in the market. In this regard, the Kazakhstan experience in launching Islamic bonds - Sukuk - could be one way of introducing a new product for the market. It would be better to create the legal bases for the particular financial instrument, which could be issued by small and medium-sized enterprises with simplified procedures on issuance, circulation, and reporting.

\section{Conclusion}

In the foregoing it has been attempted to outline the genesis, evolution, and development of the capital market in the CIS region, and to draw up key regional and some country-based specifics of the CIS embryonic capital market infrastructure and of its legal and regulatory framework. It was concluded that there were particular political, economic, and social bases for the emergence of the capital market and its infrastructure in these postSoviet jurisdictions. Especially, the collapse of USSR, the formation of CIS, the choice of the market economy as the primary means of development, privatization, and the appearance of shares and JSCs all provided fertile ground for the genesis of basic capital market institutions in post-Soviet territories. Despite the almost three decades of existence, these markets have yet to rid themselves of certain anomalies including their oligopolistic character, state and bank dominance, scarcity of professional institutions, opacity and modest corporate governance, and lack of investor confidence. This, and other consequent issues will be the subject of next researches.

\section{References}

1. Akhtamova Y. Protection of International Investments. Analysis of Certain Clauses in International Agreements. Uzbekistan Case Study //Analysis of Certain Clauses in International Agreements. Uzbekistan Case Study (March 25, 2016). - 2016.

2. Akramov A. Prospectives Of Trust Management Of Property In Uzbekistan //The American Journal of Political Science Law and Criminology. - 2020. - T. 2. - №. 11. - C. 143-150.

3. Alexander Libman and Evgeny Vinokurov, Holding-Together Regionalism: Twenty Years of Post-Soviet Integration. (Springer, 2012), 131

4. Ana Carvajal and Jennifer A. Elliott, Strengths and Weaknesses inScapital market Regulation: A Global Analysis. International Monetary Fund, 2007, 4

5. Bernard Dumas and Blaise Allaz, Financial Securities: Market Equilibrium and Pricing Methods, (Springer, 2013), 385

6. Bernard S. Black, "The legal and institutional preconditions for strong capital markets”, UCLA L. Rev. 48 (2000): 781.

7. D. Banerji, and R. Das (2014) "Understanding the Impact of Capital markets Reform on the Economy of Brazil", in Handbook of Research on Economic Growth and Technological Change in Latin America, B. Christiansen (Eds.), 21, 339-349

8. Dmitriy Vasiliev, "Capital market development in Russia”, World Bank Papers (2001).

9. Douglas W. Arner, Financial Stability,Economic Growth, and the Role of Law. (Cambridge, UK: Cambridge University Press, 2007), 14. 
10. Edward Stringham, Peter Boettke and Jeff R. Clark, “Are Regulations the Answer for Emerging Capital markets? Evidence from the Czech Republic and Poland", The Quarterly Review of Economics and Finance 48, no. 3 (2008): 541-566.

11. Eilis Ferran, "Institutional Design for Financial Market Supervision: The Choice for National Systems," University of Cambridge Faculty of Law Research Paper No. 28/2014 (2014), 10, https://papers.ssrn.com/sol3/papers.cfm?abstract_id=2425177 .

12. Ha-Joon Chang, 23 things They Don't Tell You About Capitalism. (Bloomsbury Publishing USA, 2012), 1-10.

13. J. C. Coffee, J. Seligman and H. A. Sale, Securities Regulation, (Harvard: Foundation Press, 2007), 82

14. Katharina Pistor, "Law as a Determinant for Equity Market Development: The Experience of Transition Economies",Assessing the value of law in transition economies (2001): 249-87;

15. Maidan K. Suleimenov and Farkhad S. Karagoussov, "The Legal Basis for the Capital market in the Republic of Kazakhstan", Review of Central and East European Law, 1998. Nos.5/6, 451-468,

16. Michael Golovnin, Outlook for the Joint Development of Stock Market Infrastructure in EurAsEC Countries, EDB Eurasian Integration Yearbook 2009, 142-150

17. Narziev, Otabek. "Capital market Regulation Theories and Perspectives of their Improvement." Available at SSRN 3622883 (2020).

18. Narziev, Otabek. "Problems and Prospects of Development Legal Bases of Stock Market Regulation in Uzbekistan"

19. Otabek Sadievich Narziev, "Independence and Structure of State Capital market Regulator in Uzbekistan", Annual Report on Research and Education 2014, Nagoya University, March 2015, pp. 45-87.

20. Richard J. Herring and Jacopo Carmassi. "The structure of cross-sector financial supervision", Financial Markets, Institutions \& Instruments 17, no. 1 (2008), 61.

21. Rilka Dragneva (ed). Investor Protection in the CIS: Legal Reform and Voluntary Harmonization. Vol. 57. (Martinus Nijhoff Publishers, 2007), 159.

22. Sabina Amangeldi, "Kazakhstan placed \$2.5bn Eurobonds in two tranches of 10 and 30 years", Halyk Finance, October 7, 2014, http://www.halykfinance.kz/en/site/index/research/news:90984

23. Sadievich, Narziev Otabek. "Capital market Development in CIS Countries: Legislative and Regulatory Lessons from Kazakhstan, Russia, and Uzbekistan." PhD diss., 神戸大学, 2019.

24. Turdialiev M. A., Komilov B. The Legal Issues Of International Investment Activity In Uzbekistan: Critical Analysis And Legal Solutions //The American Journal of Political Science Law and Criminology. - 2020. - T. 2. - №. 12. - C. 16-21.

25. Yuriy Kormosh, Anastasiya Burkova, "Shagi k Sozdaniyu Finansovogo Mega regulyatora v Rossii” (i.e., "Steps to Create a Financial Mega-Regulator in Russia") Rynok tsennykh bumag (Capital market) 15(318) (2006): 6972.

26. Z. M. Omarkhanova, L. R. Esbergenova, Z. A. Makisheva, and G. K. Kishibekova. "Modernization of Capital market in Kazakhstan", International Electronic Journal of Mathematics Education 11, no. 7 (2016), 2056.

27. Бутиков И. Отечественный рынок ценных бумаг: хроника событий, Октябрь, 2016. (I. Butikov, The Domestic Capital market: A Chronicle of Events, (October, 2016) http://biznes-daily.uz/ru/gazeta-birja/42715otchstvnniy-rinok-snnix-bumag-xronika-sobitiy

28. Габов, Андрей Владимирович, Проблемы гражданско-правового регулирования отношений на рынке ценных бумаг, диссертация на соискание ученой степени доктора юридических наук, Москва, 2010. (Andrey Vladimirovich Gabov, "Problems of civil-law regulation of relations in the capital market, dissertation for the degree of Doctor of Juridical Sciences", (Moscow, 2010)). Scientific Library of Dissertations and Abstracts disserCat http://www.dissercat.com/content/problemy-grazhdansko-pravovogo-regulirovaniya-otnoshenii-narynke-tsennykh-bumag\#ixzz41Rko9ObK

29. Гулямов С. С. проблемы корпоративного управления и перспективы развития законодательства Узбекистана //Государство и право: проблемы и перспективы совершенствования. - 2018. - С. 96-99.

30. Маманазаров С.Ш. Акциядорлик жамияти ижроия органи: бошқарув ва рахбарликни амалга оширишнинг хуқуқий асослари // Юрист ахборотномаси - Вестник юриста - Lawyer herald. № 6 (2020), Б. 62-66.

31. НАРЗИЕВ О.С. КАПИТАЛ БОЗОРИ БИЗНЕСНИ МОЛИЯЛАШНИНГ МУҚОБИЛ МАНБАСИ СИФАТИДА // Юрист ахборотномаси - Вестник юриста - Lawyer herald. № 6 (2020), Б. 37-44 